Research Article

\title{
Corporate Diversification, Ownership, and Solvency in China's Property-Liability Insurance Companies
}

\author{
Shuang $W u \mathbb{D}^{1}$ and Xilian Deng $\mathbb{D i D}^{2}$ \\ ${ }^{1}$ School of Finance, Hubei University of Economics, Wuhan 430205, China \\ ${ }^{2}$ School of Political Science and Law, Hubei University of Arts and Science, Xiangyang 441053, China \\ Correspondence should be addressed to Xilian Deng; tougaoyong52@163.com
}

Received 13 October 2021; Revised 12 November 2021; Accepted 10 December 2021; Published 21 December 2021

Academic Editor: Felix T.S. Chan

Copyright $(2021$ Shuang Wu and Xilian Deng. This is an open access article distributed under the Creative Commons Attribution License, which permits unrestricted use, distribution, and reproduction in any medium, provided the original work is properly cited.

\begin{abstract}
Solvency is the premise of the sustainable management of insurance companies. Among factors that affect the solvency of insurance companies, diversification strategy is one that cannot be ignored. To study the impact of diversification on the solvency of property-liability insurance companies and how diversification will influence companies with different ownership, this paper adopts the dynamic panel GMM model and the unbalanced panel data from 2009 to 2015. The analysis is from two dimensions: product diversification and geographic diversification. Empirical study shows that product diversification will increase the solvency of Chinese-funded property-liability insurance companies but reduce the solvency of foreign-funded ones. As for the impact of geographic diversification on solvency, the more geographically diversified the premium income of Chinese-funded property-liability insurance companies are, the lower their solvency will be. However, geographical expansion has no significant solvency-related impact on foreign-funded property-liability insurance companies in China.
\end{abstract}

\section{Introduction}

The diversification strategy of insurance companies is mainly manifested in two aspects; one is product diversification, and the other is geographic diversification. Due to the limitation of business policy and after considering their own advantages, property-liability (P/L) insurance companies with different ownership properties have chosen different diversification strategies. Over the past 30 years, the rapid growth of car ownership has driven the rapid growth of auto insurance, which has also led Chinese-funded P/L insurance companies to form a centralized product strategy with auto insurance at its center. However, as the loss ratio of auto insurance continues to rise and "the market-oriented reform of auto insurance rate" advances, the profit margin of $\mathrm{P} / \mathrm{L}$ insurance companies in auto insurance is declining. Chinese-funded P/L insurance companies, which mainly concentrate on auto insurance, are facing the pressure of changing their centralized business structure. Moreover, due to China's policy support for the development of nonauto insurance business, many Chinese-funded P/L insurance companies are actively diversifying their products to develop nonauto insurance business, such as liability insurance, health insurance, and accident insurance.

However, the diversification strategy of foreign-funded $\mathrm{P} / \mathrm{L}$ insurance companies is quite different. Foreign-funded $\mathrm{P} / \mathrm{L}$ insurance companies were prohibited from operating compulsory liability insurance for traffic accidents, which hindered the development of their auto insurance business. Thus, they had to turn to nonauto insurance to earn a comparative edge and form a relatively diversified business structure. It was not until May 2012 when the market of China's compulsory liability insurance for traffic accidents was fully opened to foreign insurers. Since then, foreign insurers have been allowed to operate this important type of auto insurance, which further increased the diversification of their products. With the rapid expansion of the insurance industry, $\mathrm{P} / \mathrm{L}$ insurance companies have established more branches to seize the market share. Through geographical expansion, $\mathrm{P} / \mathrm{L}$ insurance companies can not only increase 
premium income and improve profitability but also realize cross-regional diversification of underwriting risks and reduce the impact of concentrated claims on their solvency. Since the liberalization of the geographical restrictions of foreign-funded $\mathrm{P} / \mathrm{L}$ insurance companies in China has greatly reduced the cost of setting up branches, foreignfunded $\mathrm{P} / \mathrm{L}$ insurers have also begun to accelerate their institutional expansion.

Therefore, diversification has become a common choice for both Chinese-funded and foreign-funded P/L insurance companies. Diversification affects the risk of $\mathrm{P} / \mathrm{L}$ insurance companies in two ways. On the one hand, diversification brings down insurance companies' risk. A diversified combination of unrelated businesses can reduce the volatility of insurance companies' premium income and compensation expenditure. It thus reduces the chances of insolvency. Through the diversified operation, insurance companies can share resources such as customer base, marketing channels, information systems, and other business links. In this way, economies of scope and economies of scale are achieved to improve business performance and enhance solvency. On the other hand, diversification may increase the risk of insurance companies by widening the risk types, risk carriers, and risk sources. The diversification of business lines and regions may lead to the complication of management and increase information asymmetry, which will lower the management efficiency and further threaten the companies' solvency.

Does corporate diversification enhance solvency in emerging insurance markets like China? Does diversification have different effects on $\mathrm{P} / \mathrm{L}$ insurance companies with different ownership? This paper discusses the impact of corporate diversification on solvency from the two perspectives, i.e., business diversification and geographical diversification. It fills the academic gap regarding the emerging insurance market. Besides, we consider the diversified operation of foreign-funded $\mathrm{P} / \mathrm{L}$ insurance companies different from their Chinese peers, due to the limitations of their business and geographical operation. This paper contributes to the existing literature by empirically examining the impact of diversification on the solvency of Chinese-funded and foreign-funded $\mathrm{P} / \mathrm{L}$ insurance companies, respectively, and discusses the reasons.

\section{Theoretical Basis and Research Hypothesis}

\subsection{The Impact of Diversification on the Solvency of Insurance} Companies. Synergistic effect theory is one of the basic theories to explain the motivation of enterprise diversification. Thanks to economies of scope or scale, synergies in enterprises can both reduce cost and increase sales [1-4]. There are mainly three synergy benefits of diversified operation for insurance companies. Firstly, through diversification, insurance companies can share both tangible and intangible resources to reduce operating costs. Secondly, by increasing business diversification, an insurance company can obtain more customer groups through its existing crossselling channels and brand effect, thus gaining higher premium income and better efficiency of resource allocation.
Therefore, diversification is a good way for insurance companies to improve profitability and enhance solvency.

Coinsurance effect theory is another theoretical hypothesis to explain the potential benefits of diversification based on the portfolio theory. Different business departments of diversified enterprises will generate cash flows with incomplete correlation, which can reduce the risk of bankruptcy and overcome the financial constraints of enterprises [5]. Diversified enterprises are like an asset pool, in which enterprises can reduce the volatility of the overall cash flow and thus minimize their financial risks [6]. Companies operating incomplete related businesses can reduce the risk of revenue or earning fluctuations [7-9]. Shim found in his research that income diversification is beneficial to the banks since it will bring down the probability of insolvency and lessen the profit volatility [10]. The concrete manifestation of coinsurance effect theory in $\mathrm{P} / \mathrm{L}$ insurance companies is as follows: due to the irrelevance of premium income and compensation expenditure of various business lines and regions, $\mathrm{P} / \mathrm{L}$ insurers can have a more stable income and compensation expenditure through diversified portfolios. In this way, their solvency is enhanced [11]. The research took US P/L insurance companies as samples and found that $\mathrm{P} / \mathrm{L}$ insurers with the diversified business had less income fluctuation.

In addition, we can also explain the risk reduction effect of diversification according to the law of large numbers. The law of large numbers, one of the basic operation and management rules for insurance companies, points out that when the sample size is large enough, the average value of random variables will approach a stable value, which can be either probability or average. The law of large numbers requires insurance companies to accumulate many homogeneous risk subjects within the scope of their solvency. In such a manner, they will have more stable operations and more accurate calculations of premium. Through cross-regional risk distribution, the geographical diversification will help $\mathrm{P} / \mathrm{L}$ insurers reduce their underwriting risk [12], which in turn will further enhance the solvency of insurers.

After the theoretical analysis, we can propose the following hypotheses:

Hypothesis 1. (H1): according to the synergistic effect and coinsurance effect theory, product diversification will enhance the solvency of $\mathrm{P} / \mathrm{L}$ insurance companies.

Hypothesis 2. (H2): according to the synergistic effect, coinsurance effect, and the law of large numbers, regional diversification will enhance the solvency of $\mathrm{P} / \mathrm{L}$ insurance companies.

However, the principal-agent theory denies the effectiveness of the internal capital market of diversified enterprises. The theory holds that the market is not perfect and has insurmountable defects, such as information asymmetry and ineffective resource allocation. Scharfstein and Stein studied the two-level principal-agent model and pointed out that information asymmetry is more likely to cause an ineffective allocation of resources by the internal capital market of diversified enterprises [13]. Diversified companies 
tend to have longer organizational levels and management chains, which will inevitably lead to information blockage or distortion. Diversified operation brings principal-agent problems to enterprises as it increases the chances for managers to obtain personal benefits. It may affect the formulation of enterprises' strategies and investment decisions and increase the operational risks of enterprises [14]. When an insurance company conducts diversified business operations, the principal-agent problem may arise due to the increase of information asymmetry. As the insurance business becomes more complicated, its external supervision and internal management become more difficult and costly [15]. Regulatory difficulties and gaps caused by diversification will increase the probability of rent-seeking by internal managers, thus increasing enterprises' operational risks [16]. Therefore, diversification can reduce solvency risks on condition that the risk of loss due to the high volatility of new activities is lower than the expected profit margin [17].

Therefore, according to the theoretical analysis above, we propose the following hypotheses:

Hypothesis 3. (H3) : according to the principal-agent theory, product diversification will reduce the solvency of $\mathrm{P} / \mathrm{L}$ insurance companies.

Hypothesis 4. (H4) : according to the principal-agent theory, geographical diversification will reduce the solvency of $\mathrm{P} / \mathrm{L}$ insurance companies.

2.2. The impact of Ownership on the Relationship between Diversification and Solvency of Insurance Companies. Ownership has an impact on the risk taking of enterprises [18]. Barry et al. found in the study of the banking industry that different ownership structures greatly affect banks' risktaking behaviors [19]. This is particularly evident in the corporate governance of emerging markets [20]. Research on emerging markets such as Vietnam has shown that the ownership structure is strongly correlated with firm performance [21]. China's insurance market is an emerging market in the early stages of development. At the beginning of China's opening up, Chinese-funded and foreign-funded $\mathrm{P} / \mathrm{L}$ insurers had limited access to the market, in terms of operation regions and the business scopes. Therefore, they formed different product portfolios and business models. In addition, differences in market position, risk management level, and business philosophy of Chinese-funded and foreign-funded $\mathrm{P} / \mathrm{L}$ insurers also lead to differences in the impact of diversified operations on solvency.

Therefore, we propose the following hypothesis:

Hypothesis 5. (H5): diversification effects on solvency vary for $\mathrm{P} / \mathrm{L}$ insurance companies with different ownership.

\section{Sample Selection and Variable Design}

3.1. Sample Selection and Data Sources. The data of $\mathrm{P} / \mathrm{L}$ insurance companies selected in this paper are from the CSMAR database. We supplemented the missing data from
China Insurance Statistical Yearbook from 2010 to 2016. This paper was manually collected and sorted the solvency adequacy index of each company through the public annual report of the Insurance Industry Association. Macroeconomic data for this study are obtained from the website of the National Bureau of Statistics. In 2016, China began to implement the "second generation of compensation," of which the accounting method for solvency has changed since then. Therefore, the data before 2016 are selected to ensure the standardized reference of the research conclusions.

Since it was not until 2010 when China began to require $\mathrm{P} / \mathrm{L}$ insurers to disclose public information, the time interval of 2009 to 2015 was selected to include a total of 56 companies in this research. Among them, there are 38 Chinese-funded $\mathrm{P} / \mathrm{L}$ insurers and 18 foreign $\mathrm{P} / \mathrm{L}$ insurers.

\subsection{Variable}

3.2.1. Explained Variable. Solvency (sol): We refer to $\mathrm{Wu}$ and Li to use the solvency adequacy ratio as a measurement of insurers' solvency [22]. This ratio reflects the "actual capital" and "minimum capital" of the insurance company, showing the ability of an insurance company to fulfil its policy claims and payment obligations. It evaluates the operating risk of an insurance company from the perspective of risk capital. Solvency is one of the three pillars of insurance supervision in China. The guarantee of solvency is not only vital to the soundness of insurance companies' own operation but also to the protection of interests of the insured person and the policyholder. The higher the solvency adequacy ratio is, the lower the solvency risk the insurance company faces.

3.2.2. Explanatory Variable. Product diversification (prodiv): According to China's regulations on insurance supervision and management, $\mathrm{P} / \mathrm{L}$ insurance companies' calculation and operation methods need to follow related insurance types. Since 2008, the "Statistical Table of Property-Liability Insurance Company" in the China Insurance Yearbook has categorized $\mathrm{P} / \mathrm{L}$ insurance businesses into 14 types: enterprise property insurance, family property insurance, motor vehicle insurance, liability insurance, engineering insurance, cargo transportation insurance, ship insurance, credit insurance, guarantee insurance, special risk insurance, agricultural insurance, short-term health insurance, accident and injury insurance, and others. Based on these categories, this paper calculates the product diversification degree of $\mathrm{P} / \mathrm{L}$ insurers. The Herfindahl index of $\mathrm{P} / \mathrm{L}$ insurers' product diversification in the year $t$ is measured as follows:

$$
\operatorname{prodiv}_{i, t}=1-\sum_{j=1}^{n} S_{i, j, t}{ }^{2} \text {, }
$$

where $S_{i, j, t}$ is the proportion of the premium income of the $i^{-}$ th $\mathrm{P} / \mathrm{L}$ insurance company on the $j^{\text {th }}$ insurance type to the 
total premium income of the $\mathrm{P} / \mathrm{L}$ insurance company during the period $t$.

Geographical diversification (geodiv): Geographical diversification helps $\mathrm{P} / \mathrm{L}$ insurers to spread risks across regions. Carrying out insurance business across the country is conducive to $\mathrm{P} / \mathrm{L}$ insurers, as they can stabilize their premium income and compensation expenditure. Here, the geographical diversification is still measured by the Herfindahl index as

$$
\operatorname{geodiv}_{i, t}=1-\sum_{j=1}^{n} D_{i, j, t}^{2},
$$

where $D_{i, j, t}$ is the proportion of the premium income of the $i^{-}$ th $\mathrm{P} / \mathrm{L}$ insurers from the $j^{\text {th }}$ province, municipality directly under the central government or city separately listed in the plan to the total insurance income of the $\mathrm{P} / \mathrm{L}$ insurance company during the period $t$. The higher the Herfindahl index, the more geographical diversified the $\mathrm{P} / \mathrm{L}$ insurance companies are.

\subsubsection{Control Variable}

(1) Scale of a company (size): The size of an insurance company is measured by the logarithm of the company's total assets. Larger firms have more investment skills and knowledge available to control their risks [19]. However, recent studies have shown that thanks to service outsourcing, many smaller insurers can also obtain professional asset management services to reduce risks. Therefore, the correlation between the company size and insurers' robustness is not strong.

(2) Age of the company (age): The age of a company is an important characteristic of an enterprise. As a firm grows older, its risk preference goes down [23]. Older companies have accumulated more experience through the "learning effect," [24] so they can better control the solvency risk. The firm age is equal to the sample year minus the year in which the firm was established. In this paper, the logarithm of the firm age is taken.

(3) Loss ratio (loss): The higher the loss ratio of an insurer is, the greater solvency impact it will achieve. A high loss ratio means a heavy outflow of cash from the insurance company. This ratio is equal to the ratio of indemnity expenses to the premium income.

(4) Reinsurance (rein): Reinsurance is measured by the reinsurance ratio, which is equal to the ratio of ceding premium to the total premium. As an important way to transfer risks, reinsurance allows insurers to transfer a part of their risks for soundness operation. Therefore, we expect a positive correlation between reinsurance and solvency.

(5) Market shares (ms): The market share of an insurance company is the proportion of its premium income compared to the total premium income of the industry during a certain period. The larger market share the insurance company takes up, the more attention and supervision it receives from the public and the government. Therefore, insurers with a larger market share will concentrate more on solvency management.

(6) Investment risk (investrisk): In the investment business of the insurance company, the relatively stable and less risky types of investment include fixed deposit, bond investment, and interbank lending. The solvency risk of a $\mathrm{P} / \mathrm{L}$ insurance company is negatively correlated with its risky assets [25]. Investment risk refers to the ratio of risky assets to total assets, and risky assets are the total assets minus stable assets.

(7) Gross domestic product (gdp): As macroeconomic factors will affect the solvency risk of P/L insurers, this paper controls such factors to eliminate the effect. It chooses the growth rate of gross domestic product (GDP) as the measurement of macroeconomic factors.

3.3. Model Construction. To solve the endogeneity problem and generate accurate and effective estimation, this paper builds the following GMM dynamic panel model. This model, which is shown as follows, reflects how diversified operation will influence P/L insurers' solvency [26]:

$$
\begin{gathered}
\operatorname{sol}_{i, t}=\alpha_{0}+\alpha_{1} \operatorname{sol}_{i, t-1}+\alpha_{2} \operatorname{prodiv}_{i, t}+\alpha_{3} \operatorname{control}_{i, t-1}+\mu_{i, t}, \\
\operatorname{sol}_{i, t}=\beta_{0}+\beta_{1} \operatorname{sol}_{i, t-1}+\beta_{2} \operatorname{geodiv}_{i, t}+\beta_{3} \operatorname{control}_{i, t-1}+\varepsilon_{i, t} .
\end{gathered}
$$

Models (3) and (4) are used to test the impacts of business diversification and geographical diversification on the solvency risk of $\mathrm{P} / \mathrm{L}$ insurers, respectively, where prodiv ${ }_{i, t}$

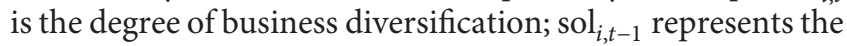
solvency risk of one lagging period, considering the hysteresis of risks; geodiv ${ }_{i, t}$ is the degree of geographical diversification of $\mathrm{P} / \mathrm{L}$ insurance companies; control $_{i, t-1}$ represents a series of control variables, including the age of the company, the loss rate, reinsurance, investment risk, and GDP growth rate. $\varepsilon_{i, t}$ and $\mu_{i, t}$ are the error terms.

\section{Empirical Result}

4.1. Descriptive Statistics of Variables. Table 1 lists the descriptive statistical results of the relevant variables. The average level the of solvency adequacy ratio of $\mathrm{P} / \mathrm{L}$ insurance companies in China is 18.91. The average solvency adequacy ratio of foreign-funded $\mathrm{P} / \mathrm{L}$ insurance companies is 27.21 , which is higher than that of their Chinese peers, which is 14.30. In terms of the degree of business diversification, foreign-funded $\mathrm{P} / \mathrm{L}$ insurance companies register 0.608 , which is much higher than the degree of 0.383 for their Chinese peers. These data are consistent with the reality that the business structure of foreign-funded $\mathrm{P} / \mathrm{L}$ insurers in China is dispersed, while for Chinese-funded $\mathrm{P} / \mathrm{L}$ insurers, it 
TABle 1: Descriptive statistics of variables.

\begin{tabular}{|c|c|c|c|c|c|}
\hline & Variable & Mean value & Standard deviation & Minimum value & Maximum value \\
\hline \multirow{10}{*}{ Full sample } & Sol & 18.91 & 67.63 & 0.52 & 898.4 \\
\hline & Prodiv & 0.472 & 0.199 & 0.015 & 0.884 \\
\hline & Geodiv & 0.609 & 0.362 & 0 & 0.959 \\
\hline & Size & 8.079 & 1.660 & 5.188 & 13.59 \\
\hline & Age & 2.062 & 0.775 & 0 & 4.220 \\
\hline & Loss & 0.438 & 0.431 & 0 & 6.880 \\
\hline & Rein & 0.228 & 0.234 & 0 & 0.971 \\
\hline & $\mathrm{ms}$ & 0.019 & 0.058 & 0 & 0.421 \\
\hline & Investrisk & 0.651 & 0.196 & 0.137 & 0.985 \\
\hline & $\operatorname{gdp}$ & 0.083 & 0.013 & 0.067 & 0.106 \\
\hline \multirow{10}{*}{ Sample of Chinese-funded companies } & Sol & 14.30 & 50.10 & 0.52 & 315.5 \\
\hline & Prodiv & 0.383 & 0.164 & 0.015 & 0.844 \\
\hline & Geodiv & 0.778 & 0.284 & 0 & 0.959 \\
\hline & Size & 8.910 & 1.541 & 6.189 & 13.59 \\
\hline & Age & 2.054 & 0.821 & 0 & 4.220 \\
\hline & Loss & 0.435 & 0.160 & 0 & 0.779 \\
\hline & Rein & 0.113 & 0.103 & 0 & 0.734 \\
\hline & $\mathrm{ms}$ & 0.030 & 0.072 & 0 & 0.421 \\
\hline & Investrisk & 0.733 & 0.169 & 0.238 & 0.985 \\
\hline & gdp & 0.083 & 0.013 & 0.067 & 0.106 \\
\hline \multirow{10}{*}{ Sample of foreign-funded companies } & Sol & 27.21 & 90.77 & 1.077 & 898.4 \\
\hline & Prodiv & 0.608 & 0.170 & 0.022 & 0.833 \\
\hline & Geodiv & 0.349 & 0.315 & 0 & 0.922 \\
\hline & Size & 6.818 & 0.834 & 5.188 & 9.325 \\
\hline & Age & 2.077 & 0.701 & 0 & 3.135 \\
\hline & Loss & 0.442 & 0.653 & 0 & 6.880 \\
\hline & Rein & 0.404 & 0.267 & 0.001 & 0.971 \\
\hline & $\mathrm{ms}$ & 0.001 & 0.001 & 0 & 0.009 \\
\hline & Investrisk & 0.527 & 0.169 & 0.137 & 0.947 \\
\hline & gdp & 0.083 & 0.013 & 0.067 & 0.106 \\
\hline
\end{tabular}

is concentrated. As for the degree of geographical diversification, Chinese-funded insurance companies get 0.778 and foreign-funded ones obtain only 0.349. Chinese-funded insurers are more geographically diversified than foreignfunded insurers. This may be due to the restrictions on foreign-funded insurance companies at the beginning of China's opening up, when foreign insurers only got limited business scope, geographically.

4.2. The Estimation Test of the Models. This paper empirically examines the impact of diversification on insurance companies' risks based on the differences between Chinesefunded and foreign-funded P/L insurance companies. In this model, GMM (Generalized Moment Method), the dynamic panel model of the system is used for estimation. The lag period of solvency is taken as an explanatory variable to solve the endogenous problem. According to the results of AR (2) and Sargan test, there is no sequence correlation and excessive identification of instrumental variables. Therefore, this model is reasonably set.

4.2.1. The Impact of Business Diversification on Solvency. Table 2 displays the regression results of the impact of business diversification on solvency. Columns (1), (2), and
TABle 2: The impact of business diversification on solvency.

\begin{tabular}{lccc}
\hline Variable & Full sample & Chinese-funded & Foreign-funded \\
\hline \multirow{4}{*}{ L.sol } & $(1)$ & $(2)$ & $(3)$ \\
& $0.037^{* * *}$ & $0.008^{* * *}$ & $0.042^{* * *}$ \\
Prodiv & $(37.615)$ & $(6.546)$ & $(19.024)$ \\
& $6.240^{* *}$ & $5.719^{* * *}$ & $-10.870^{* * *}$ \\
Size & $(2.194)$ & $(4.391)$ & $(-2.875)$ \\
& $4.541^{* * *}$ & $4.852^{* * *}$ & 0.389 \\
Age & $(5.568)$ & $(16.663)$ & $(0.293)$ \\
& $-11.260^{* * *}$ & $-13.771^{* * *}$ & $-10.768^{* * *}$ \\
Loss & $(-8.909)$ & $(-18.773)$ & $(-7.177)$ \\
& $1.906^{* * *}$ & $7.104^{* * *}$ & 2.083 \\
Rein & $(9.981)$ & $(6.219)$ & $(0.902)$ \\
& $11.599^{* *}$ & $12.859^{* * *}$ & $41.641^{* * *}$ \\
ms & $(2.447)$ & $(5.804)$ & $(7.244)$ \\
& -83.371 & $-134.467^{* * *}$ & $-1,033.972$ \\
Investrisk & $(-1.217)$ & $(-2.996)$ & $(-0.414)$ \\
& $-3.271^{* *}$ & $1.992^{* * *}$ & -15.813 \\
gdp & $(-2.297)$ & $(4.659)$ & $(-1.298)$ \\
& 29.242 & $-109.412^{* * *}$ & $147.254^{* * *}$ \\
Constant & $(1.278)$ & $(-6.250)$ & $(6.204)$ \\
& $-10.615^{* *}$ & $-5.967^{*}$ & $19.370^{* * *}$ \\
N & $(-1.962)$ & $(-1.942)$ & $(3.223)$ \\
AR (2) test & 268 & 170 & 98 \\
Sargan test & $(0.562)$ & $(0.910)$ & $(0.875)$ \\
\hline & $(0.070)$ & $(0.090)$ & $(0.954)$ \\
\hline
\end{tabular}

Note. $* * *$ means $P<0.01, * *$ means $P<0.05$, and $*$ means $P<0.1$. 
(3) are the regression results of the full sample, the Chinese-funded sample, and the foreign-funded sample, respectively. Overall, business diversification has a significant positive impact on the solvency of $\mathrm{P} / \mathrm{L}$ insurers by reducing their solvency risks. In the sample of Chinese-funded companies, there is a positive correlation between business diversification and solvency at a significant level of $1 \%$. In other words, more business diversification will reduce Chinesefunded P/L insurers' solvency risk. As for business structure, most Chinese-funded P/L insurance companies mainly focus on auto insurance. However, auto insurance industries experienced serious losses in recent years. Therefore, Chinesefunded $\mathrm{P} / \mathrm{L}$ insurers changed their auto insurance-centralized business model to a more diversified business model. Such transformation not only unlocked new sources of profitable growth for them but also improved their solvency. Through the diversified combination of unrelated businesses, the volatility of their premium income and compensation expenditure was reduced and the coinsurance effect was achieved. In this way, the insurers successfully minimized their risks for a long time.

However, according to the regression results of foreignfunded companies, the coefficient between business diversification and solvency is significantly negative at the level of $1 \%$. In other words, more diversified business is not conducive to the solvency enhancement for them. Since the market of China's compulsory liability insurance for traffic accidents was fully opened to foreign insurers, the operating restrictions of foreign-funded P/L insurance companies in China have been lifted, and many foreign-funded insurance companies have begun to operate auto insurance business. However, the degree of business diversification has a negative impact on the solvency. As newcomers to the China's auto insurance market, foreign-funded $\mathrm{P} / \mathrm{L}$ insurers do not have sufficient knowledge of customers or enough data on related auto insurance claims. Therefore, in the short term, they cannot benefit from the beginning. Moreover, new business means higher input and excessive compensation and income risks. These factors have adversely affected the solvency of foreign-funded P/L insurance companies.

\subsubsection{The Impact of Geographical Diversification on Solvency.}

Table 3 shows the empirical regression results of geographical diversification's impact on solvency. Overall, there is a significant negative correlation between the degree of geographical diversification and solvency of $\mathrm{P} / \mathrm{L}$ insurers at the level of $1 \%$. For Chinese-funded P/L insurers, geographical diversification is positively correlated with solvency at the significant level of $1 \%$. According to the empirical results, geographical diversification cannot spread risks or enhance the solvency for Chinese-funded P/L insurers. On the contrary, rapid expansion and establishment of new branches lead to asymmetric information of Chinese-funded $\mathrm{P} / \mathrm{L}$ insurers. Triggered by asymmetric information, the principalagent problems occur, which make risk control more difficult and the solvency of insurance companies worse.

However, according to the regression results of foreignfunded $\mathrm{P} / \mathrm{L}$ insurers' sample, the correlation between
TABLE 3: The impact of geographical diversification on solvency.

\begin{tabular}{lccc}
\hline Variable & Full sample & Chinese-funded & Foreign-funded \\
\hline \multirow{2}{*}{ L.sol } & $(1)$ & $(2)$ & $(3)$ \\
& $0.033^{* * *}$ & $0.004^{*}$ & $0.037^{* * *}$ \\
Geodiv & $(21.315)$ & $(1.684)$ & $(25.938)$ \\
& $-15.158^{* * *}$ & $-16.792^{* * *}$ & -5.977 \\
Size & $(-4.492)$ & $(-15.085)$ & $(-1.477)$ \\
& $5.377^{* * *}$ & $5.674^{* * *}$ & 0.646 \\
Age & $(11.658)$ & $(11.844)$ & $(0.578)$ \\
& $-10.152^{* * *}$ & $-9.195^{* * *}$ & $-11.972^{* * *}$ \\
Payrate & $(-6.773)$ & $(-5.931)$ & $(-7.667)$ \\
& $2.873^{* * *}$ & $6.450^{* * *}$ & 2.305 \\
Rein & $(8.237)$ & $(4.694)$ & $(1.556)$ \\
& $10.461^{* *}$ & $9.314^{* *}$ & $32.272^{* * *}$ \\
ms & $(2.154)$ & $(2.391)$ & $(4.912)$ \\
& -79.194 & $-88.264^{* *}$ & $-1,274.190$ \\
Investrisk & $(-1.058)$ & $(-2.559)$ & $(-0.694)$ \\
& $-4.685^{* * *}$ & 0.141 & $-12.783^{* *}$ \\
gdp & $(-3.626)$ & $(0.119)$ & $(-2.328)$ \\
& 11.789 & $-47.052^{* *}$ & $119.361^{* * *}$ \\
Constant & $(0.503)$ & $(-2.498)$ & $(5.212)$ \\
& $-5.220^{* *}$ & $-11.000^{* * *}$ & $20.004^{* * *}$ \\
N & $(-1.968)$ & $(-3.204)$ & $(3.421)$ \\
AR $(2)$ test & 268 & 170 & 98 \\
Sargan test & $(0.194)$ & $(0.085)$ & $(0.829)$ \\
\hline Note. ${ }^{* * *}$ means & $P<0.01,{ }^{* *}$ means $P<0.05$, and ${ }^{*}$ means $P<0.1$. \\
& & & $(0.958)$ \\
& & $(0.405)$ &
\end{tabular}

geographical diversification and the solvency is not significant. This may be due to the geographical restrictions imposed on foreign-funded insurers in the early days of China's opening up. Previous restrictions provided foreign-funded insurance companies limited access to geographical diversification. As a result, they had to concentrate in the eastern and central regions of China [27]. After the restrictions are lifted, geographical diversification cannot improve the performance or diversify risks for foreign-funded companies, and the principalagent problem caused by geographical diversification is not prominent. Therefore, the impact of geographical diversification on the solvency of foreign-funded insurance companies is not significant.

\section{Robustness Test}

Referred to the existing research, we need to further test the robustness of the conclusion. We use entropy index as the proxy variable of Herfindahl index to measure the degree of product diversification and geographical diversification of insurance companies. Compared with the Herfindahl index, the entropy index has a wider range of values.

Following Krivokapic et al. [28], we use the entropy index to measure the product diversification degree of $\mathrm{P} / \mathrm{L}$ insurance companies as follows:

$$
e-\operatorname{prodiv}_{i, t}=\sum_{j=1}^{n} S_{i, j, t} \ln \left(\frac{1}{S_{i, j, t}}\right),
$$

where $S_{i, j, t}$ is the proportion of the premium income of the $i^{-}$ th $\mathrm{P} / \mathrm{L}$ insurance company on the $j^{- \text {th }}$ insurance type to the 
TABle 4: The impact of business diversification (measured by entropy number) on solvency.

\begin{tabular}{lccc}
\hline Variable & Full sample & Chinese-funded & Foreign-funded \\
\hline \multirow{4}{*}{ L.sol } & $(1)$ & $(2)$ & $(3)$ \\
& $0.044^{* * *}$ & $0.023^{* * *}$ & $0.040^{* * *}$ \\
e-prodiv & $(91.698)$ & $(49.630)$ & $(50.676)$ \\
& $3.106^{*}$ & $7.287^{* * *}$ & $-4.455^{* * *}$ \\
Size & $(1.707)$ & $(4.983)$ & $(-3.383)$ \\
& $3.298^{* * *}$ & $2.031^{* * *}$ & 0.766 \\
Age & $(9.729)$ & $(7.956)$ & $(0.527)$ \\
& $-12.480^{* * *}$ & $-10.778^{* * *}$ & $-9.358^{* * *}$ \\
Payrate & $(-11.148)$ & $(-24.671)$ & $(-5.937)$ \\
& $1.914^{* * *}$ & $4.752^{* * *}$ & 0.518 \\
Rein & $(8.543)$ & $(4.523)$ & $(0.872)$ \\
& $15.308^{* * *}$ & $10.312^{* * *}$ & $40.270^{* * *}$ \\
ms & $(4.097)$ & $(3.881)$ & $(5.712)$ \\
& -94.840 & $-135.375^{* * *}$ & $-4,448.806$ \\
Investrisk & $(-1.259)$ & $(-3.496)$ & $(-0.926)$ \\
& $-3.044^{* * *}$ & $-1.277^{* * *}$ & -8.836 \\
Gdpgrowth & $(-2.820)$ & $(-3.688)$ & $(-1.290)$ \\
& -25.524 & $-119.584^{* * *}$ & $146.557^{* * *}$ \\
Constant & $(-0.936)$ & $(-9.009)$ & $(7.741)$ \\
& $6.341^{* *}$ & $17.712^{* * *}$ & $10.690^{* * *}$ \\
N & $(2.005)$ & $(5.397)$ & $(2.784)$ \\
AR (2) test & 268 & 178 & 98 \\
Sargan test & $(0.531)$ & $(0.358)$ & $(0.696)$ \\
\hline & $(0.204)$ & $(0.368)$ & $(0.949)$ \\
\hline
\end{tabular}

Note. ${ }^{* * *}$ means $P<0.01,{ }^{* *}$ means $P<0.05$, and ${ }^{*}$ means $P<0.1$.

total premium income of the $\mathrm{P} / \mathrm{L}$ insurance company during the period $t$.

The geographical diversification degree of $\mathrm{P} / \mathrm{L}$ insurance companies measured by the entropy index is as follows:

$$
e-\operatorname{geodiv}_{i, t}=\sum_{j=1}^{n} D_{i, j, t} \ln \left(\frac{1}{D_{i, j, t}}\right),
$$

where $D_{i, j, t}$ is the proportion of the premium income of the $i^{-}$ th $\mathrm{P} / \mathrm{L}$ insurance company from the $j^{\text {th }}$ province, municipality directly under the central government or city separately listed in the plan to the total insurance income of the $\mathrm{P} / \mathrm{L}$ insurance company during the period $t$.

Table 4 shows the results of the robustness test with the dynamic GMM method. The business diversification measured by the entropy index is taken as a proxy index. The empirical results in Table 4 show that when Chinese-funded $\mathrm{P} / \mathrm{L}$ insurance companies diversify their business, their solvency will increase, while the business diversification of foreign-funded $\mathrm{P} / \mathrm{L}$ insurance companies only witnesses lower solvency. This result is consistent with previous research conclusions, and the robustness test is passed.

Table 5 shows the robustness test results of the dynamic GMM method when the geographical diversification, which is measured by the number of entropy values, serves as the proxy index. According to the empirical results, the geographical diversification will reduce the solvency of Chinesefunded $\mathrm{P} / \mathrm{L}$ insurance companies while exerting no significant impact on the solvency of foreign-funded P/L insurance companies. Hence, the robustness test results are consistent with the geographical empirical results.
TABLE 5: The impact of geographical diversification (measured by entropy number) on solvency.

\begin{tabular}{lccc}
\hline Variable & Full sample & Chinese-funded & Foreign-funded \\
\hline \multirow{4}{*}{ L.sol } & $(1)$ & $(2)$ & $(3)$ \\
& $0.034^{* * *}$ & $0.005^{* * *}$ & $0.041^{* * *}$ \\
e-geodiv & $(37.819)$ & $(3.663)$ & $(17.084)$ \\
& $-5.675^{* * *}$ & $-9.064^{* * *}$ & 1.734 \\
Size & $(-8.895)$ & $(-41.251)$ & $(0.900)$ \\
& $5.967^{* * *}$ & $8.041^{* * *}$ & 0.049 \\
Age & $(6.064)$ & $(25.270)$ & $(0.039)$ \\
& $-7.679^{* * *}$ & $-4.586^{* * *}$ & $-12.662^{* * *}$ \\
Payrate & $(-4.767)$ & $(-3.786)$ & $(-5.881)$ \\
& $1.971^{* * *}$ & $6.469^{* * *}$ & 2.128 \\
Rein & $(7.991)$ & $(3.403)$ & $(1.298)$ \\
& $13.760^{* * *}$ & 3.156 & $42.315^{* * *}$ \\
ms & $(3.226)$ & $(1.559)$ & $(4.841)$ \\
& -65.050 & -29.031 & 903.442 \\
Investrisk & $(-0.842)$ & $(-0.919)$ & $(0.191)$ \\
& $-3.619^{* *}$ & $-1.817^{* * *}$ & -16.448 \\
Gdpgrowth & $(-2.334)$ & $(-2.619)$ & $(-1.605)$ \\
& 29.942 & 11.278 & $136.345^{* * *}$ \\
Constant & $(1.599)$ & $(0.544)$ & $(5.726)$ \\
& -11.977 & $-26.336^{* * *}$ & $15.615^{* * *}$ \\
N & $(-1.613)$ & $(-9.507)$ & $(4.332)$ \\
AR (2) test & 268 & 178 & 98 \\
Sargan test & $(0.531)$ & $(0.982)$ & $(0.696)$ \\
\hline & $(0.204)$ & $(0.213)$ & $(0.949)$ \\
\hline
\end{tabular}

Note: ${ }^{* * *}$ means $P<0.01,{ }^{* *}$ means $P<0.05$, and ${ }^{*}$ means $P<0.1$.

\section{Conclusions and Suggestions}

We manually collect the solvency adequacy ratio data of 38 Chinese-funded P/L insurance companies and 18 foreignfunded $\mathrm{P} / \mathrm{L}$ insurance companies in China, using the Herfindahl index to measure the product diversification and geographical diversification of these companies, and build the dynamic panel GMM model to empirically test the impact of product diversification and geographical diversification on their solvency. The empirical study finds that product diversification will significantly increase the solvency of Chinese-funded $\mathrm{P} / \mathrm{L}$ insurance companies but negatively affect that of foreign-funded $\mathrm{P} / \mathrm{L}$ insurance companies. In addition, geographical diversification will significantly reduce the solvency of Chinese-funded $\mathrm{P} / \mathrm{L}$ insurance companies. As for foreign-funded $\mathrm{P} / \mathrm{L}$ insurance companies, the negative impact of geographical diversification on solvency is not prominent.

Based on the research conclusions above and the reality of China's insurance market, this paper puts forward the following suggestions:

With the advancement of market-oriented premium rates in China's $\mathrm{P} / \mathrm{L}$ insurance market, the competition in the insurance market becomes more and more fierce. Chinesefunded $\mathrm{P} / \mathrm{L}$ insurance companies have to change their product structure from the auto-insurance-centered one to a more diversified one. Chinese-funded companies should seize the opportunity to strengthen the management and profitability of the auto insurance business. Meanwhile, Chinese-funded P/L insurance companies should actively explore a nonauto insurance business, take advantage of the 
scope economy effect of business diversification, unlock more resources of premium income, and improve profitability. In this way, their solvency will be enhanced. However, when Chinese-funded companies expand geographically, they should prevent the growth of information asymmetry caused by blind expansion and strengthen the supervision of underwriting and claim settlement in the business development of branch offices. In this way, the adverse impact of principal-agent problems can be reduced, and management inefficiency can be avoided. Chinese-funded $\mathrm{P} / \mathrm{L}$ insurance companies will better achieve solvency during geographical expansion.

Foreign companies should enter the auto insurance market step by step, gradually accumulating claims the data of auto insurance and business experience and actively carry out customer research. When entering the new market, they should overcome culture shock and prevent the adverse impact on solvency. Meanwhile, as China further opens the insurance industry, foreign $\mathrm{P} / \mathrm{L}$ insurers have fewer restrictions on geographical expansion. During geographical diversification, they should strengthen management and guard against solvency risk.

\section{Data Availability}

The data used to support the findings of this study are available from the corresponding author upon request.

\section{Conflicts of Interest}

The authors declare that there are no conflicts of interest regarding the publication of this paper.

\section{Acknowledgments}

This study was supported by the Humanities and Social Science Research Project of Ministry of Education (grant no. 21YJA790032). And the title of the project is the Empirical Test and Control Strategy research of Farmers' Moral Hazard in the Pilot Program of Total Cost Insurance for Grain Crops: based on the Investigation of Pilot Counties in Shandong and Hubei Provinces.

\section{References}

[1] T. H. Brush, "Predicted change in operational synergy and post-acquisition performance of acquired businesses," Strategic Management Journal, vol. 17, no. 1, pp. 1-24, 1996.

[2] R. Davis and I. M. Duhaime, "Diversification, vertical integration, and industry analysis: new perspectives and measurement," Strategic Management Journal, vol. 13, no. 7, pp. 511-524, 1992.

[3] D. J. Miller, "Technological diversity, related diversification, and firm performance," Strategic Management Journal, vol. 27, no. 7, pp. 601-619, 2006.

[4] J. A. Robins and M. F. Wiersema, "The measurement of corporate portfolio strategy: analysis of the content validity of related diversification indexes," Strategic Management Journal, vol. 24, no. 1, 2003.
[5] W. G. Lewellen, "A pure financial rationale for the conglomerate merger," The Journal of Finance, vol. 26, no. 2, pp. 521-537, 1971.

[6] R. Amit and J. Livnat, "Diversification and the risk-return trade-off," Academy of Management Journal, vol. 31, no. 1, pp. 154-166, 1988.

[7] V. Chiorazzo, C. Milani, and F. Salvini, "Income diversification and bank performance: evidence from Italian banks," Journal of Financial Services Research, vol. 33, no. 3, pp. 181-203, 2008.

[8] M. Gort, Diversification and Integration in American Industry, Princeton University Press, Princeton, NJ, USA, 1962.

[9] E. Penrose, "Theory of the growth of the firm," Journal of the Operational Research Society, vol. 23, no. 2, pp. 240-241, 1995.

[10] J. Shim, "Bank capital buffer and portfolio risk: the influence of business cycle and revenue diversification," Journal of Banking \& Finance, vol. 37, no. 3, pp. 761-772, 2013.

[11] A. P. Liebenberg and D. W. Sommer, "Effects of corporate diversification: evidence from the property-liability insurance industry," Journal of Risk \& Insurance, vol. 75, no. 4, pp. 893-919, 2008.

[12] C. Xin and A. P. Liebenberg, "Effects of business diversification on asset risk-taking: evidence from the U.S. propertyliability insurance industry," Journal of Banking \& Finance, vol. 77, pp. 122-136, 2017.

[13] D. S. Scharfstein and J. C. Stein, "The dark side of internal capital markets: divisional rent-seeking and inefficient investment," The Journal of Finance, vol. 55, no. 6, pp. 2537-2564, 2000.

[14] M. C. Jensen, "Agency cost of free cash flow, corporate finance," The American Economic Review, vol. 76, no. 2, pp. 323-329, 1986.

[15] H. L. Wei and N. Liu, "Economic Analysis of the integrative development of insurance market and capital market," Economic Review, vol. 142, no. 6, pp. 99-104, 2006.

[16] N. Liu, J. Yi, and H. W. Yang, "A risk analysis on diversified operation of life insurance company in China," The Theory and Practice of Finance and Economics, vol. 35, no. 3, pp. 26-30, 2014.

[17] R. C. Castro and A. G. Mejía, "Effect of trading on the profitability and solvency of Colombian banks," Journal of Management, vol. 35, no. 63, pp. 55-69, 2019.

[18] L. Gao, "Is the property right or market competition conducive to firm performance? -Based on the perspective of risk taking," Research on Economics and Management, vol. 39, no. 1, pp. 138-146, 2018.

[19] T. Barry, S. J. I. O. Dacanay, A. Tarazi, and L. Lepetit, "Ownership structure and bank efficiency in the asia pacific region," Working Papers, 2008.

[20] S. Faysal, M. Salehi, and M. Moradi, "Impact of corporate governance mechanisms on the cost of equity capital in emerging markets," Journal of Public Affairs, vol. 21, no. 2, p. e2166, 2021.

[21] D. N. Phung, Ownership Structure, Corporate Diversification, and Firm Performance: A Study of Listed Firms in Vietnam, Thesis Collection, Western Sydney University, Greater Western Sydney, NSW, Australia, 2015.

[22] S. Wu and Y. Li, "Impact of the business structure on solvency of property-liability insurance companies and its mediating effect," Discrete Dynamics in Nature and Society, vol. 2021, Article ID 5457846, 17 pages, 2021.

[23] M. Salehi, A. Arianpoor, and N. Naghshbandi, "The relationship between managerial attributes and firm risk-taking," TQM Journal (ahead-of-print), 2021. 
[24] S. W. Pottier, "The determinants of private debt holdings: evidence from the life insurance industry," Journal of Risk \& Insurance, vol. 74, no. 3, pp. 591-612, 2007.

[25] S.-J. Lee, D. Mayers, and C. W. W. S. Smith, "Guaranty funds and risk-taking evidence from the insurance industry," Journal of Financial Economics, vol. 44, no. 1, pp. 3-24, 1997.

[26] M. Salehi, M. S. Adibian, Z. Sadatifar, and E. Khansalar, "The relationship between corporate governance characteristics and agency costs," Zbornik Radova Ekonomskog Fakulteta U. Rijeci: Casopis Za Ekonomsku Teoriju I praksu/Proceedings of Rijeka Faculty of Economics: Journal of Economics and Business, vol. 39, no. 1, pp. 199-220, 2021.

[27] X. N. Wang, "Parent country composition, location distribution and business structure of foreign insurance companies-Analysis on the 10th Anniversary of China's entry into WTO," Insurance Studies, vol. 32, no. 12, pp. 11-17, 2011.

[28] R. Krivokapic, V. Njegomir, and D. Stojic, "Effects of corporate diversification on firm performance: evidence from the Serbian insurance industry," Economic Research-Ekonomska Istraživanja, vol. 30, no. 1, pp. 1224-1236, 2017. 